\title{
Hubungan Curah Hujan dengan Kasus Demam Berdarah Dengue di Bandar Lampung 2016-2018
}

\author{
Tusy Triwahyuni ${ }^{1}$, Ismalia Husna ${ }^{2}$, Melisa Andesti ${ }^{3}$ \\ ${ }^{1)}$ Fakultas Kedokteran Universitas Malahayati, Bandar Lampung \\ ${ }^{2}$ Fakultas Kedokteran Universitas Malahayati, Bandar Lampung \\ ${ }^{3}$ Universitas Malahayati, Bandar Lampung,mel_andesti@yahoo.com
}

\begin{abstract}
ABSTRAK
Demam berdarah dengue (DBD) adalah penyakit yang disebabkan oleh virus dengue melalui vektor nyamuk yang paling cepat penyebarannya di dunia. Tahun 1968 hingga tahun 2009, WHO mencatat negara Indonesia dengan kasus DBD tertinggi di Asia Tenggara. Angka kejadian DBD tersebut dikarenakan beberapa faktor. Salah satu faktornya yaitu curah hujan. Penelitian ini bertujuan untuk mengetahui hubungan antara curah hujan dengan kasus demam berdarah dengue (DBD) di Kota Badar Lampung Tahun 2016-2018. Penelitian ini merupakan penelitian analitik korelasi dengan data sekunder dari BMKG dan Dinkes Kota Bandar Lampung. Data dianalisis dengan uji bivariat Spearman. Penelitian dilakukan selama bulan Januari 2020 hingga Februari 2020. Total sampling digunakan dengan jumlah sampel 36 dari BMKG dan Dinkes kota Bandar Lampung tahun 2016-2018. Hasil penelitian menunjukkan bahwa distribusi curah hujan menunjukan bahwa pada tahun 2016 -2018 curah hujan tertinggi terjadi pada Februari dengan angka rata-rata 218,3mm. Angka kasus DBD tertinggi terjadi pada Maret dengan jumlah rata-rata 136 kasus. Hasil pengujian korelasi curah hujan dan kasus DBD menunjukkan nilai $r$ sebesar 0,451, $N$ sebesar 36 sampel dan signifikasi 0,006. Terdapat hubungan curah hujan dengan kasus DBD di Kota Bandar Lampung Tahun 2016-2018 dengan kekuatan korelasi sedang dan arah positif.
\end{abstract}

Kata kunci : curah hujan, demam berdarah dengue, iklim

\section{ABSTRACT}

Dengue hemorrhagic fever (DHF) is disease caused by dengue virus through mosquito as the vector, which spread rapidly. Meanwhile, since 1968 until 2009 WHO determined Indonesia as a country with the highest DHF incidence in South-east asia Departement of Health of Bandar Lampung City. The study aim to know the correlation of rainfall and dengue incidence in Bandar Lampung City Periode 2016-2018. This analytic study performed correlation approach. Secondary data sources from BMKG and Departement of Health of Bandar Lampung City were obtained. Analyzing data was using SPSS 19. This research was done during January 2020 until February 2020. There were 36 samples from BMKG and department of health of Bandar Lampung city periode 2016-2018 taken using total sampling method. Result show the heaviest rainfall in 2016-2018 recorded in February with average 218,3 mm. The most DHF incidence recorded in March with average 136 incidences. The correlation test shown $r=0,451, N=36$, signification 0,006. There is a correlation between rainfall and DHF incidence with average correlation strength in positive direction.

Keywords : rainfall, dengue hemorrhagic fever, climate

*Korespondensi Author : Melisa Andesti, Fakultas Kedokteran Universitas Malahayati, mel_andesti@yahoo.com,087871415777.

\section{PENDAhULUAN}

Demam berdarah dengue (DBD) adalah penyakit yang disebabkan oleh virus dengue dan ditularkan melalui gigitan nyamuk Aedes aegypti yang paling cepat penyebarannya di dunia. ${ }^{1}$ Host alami dari DBD adalah manusia, agen nya adalah virus dengue yang termasuk ke dalam family Flaviviridae dan genus Flavivirus, terdiri dari 4 serotipe yaitu DEN-1, DEN-2,
DEN-3, dan DEN-4.DBD ditularkan ke manusia melalui gigitan nyamuk yang terinfeksi. ${ }^{2}$ Bila penderita tersebut digigit nyamuk penular, maka virus dalam darah akan ikut terhisap masuk dalam lambung nyamuk. Selanjutnya virus akan memperbanyak diri dan tersebar di berbagai jaringan tubuh nyamuk yang mana akan bersirkulasi keseluruh bagian tubuh termasuk di dalam kelenjar liurnya. ${ }^{3}$ 
Kurang lebih 1 minggu setelah menghisap darah penderita, nyamuk tersebut siap untuk menularkan kepada orang lain (masa inkubasi ektrinsik). Virus ini akan tetap berada dalam tubuh nyamuk sepanjang hidupnya. Oleh karena itu nyamuk Aedes aegypti yang telah menghisap virus dengue ini menjadi penular (infektif) DBD sepanjang hidupnya. Nyamuk Aedes aegypti mengalami metamorposis sempurna. Pada stadium telur, larva dan pupa hidup di dalam air, sedangkan stadium dewasa hidup diluar air. Dalam suasana yang optimal, perkembangan dari telur menjadi dewasa memerlukan waktu sedikitnya 9 hari. $^{3}$

Distribusi kasus DBD sangat dipengaruhi oleh faktor lingkungan. Faktor lingkungan fisik yang berpengaruh terhadap kehidupan vektor adalah curah hujan, temperatur, evaporasi, kandungan air kontainer, seperti bahan organik, komunitas mikroba, dan serangga air yang ada dalam kontainer. ${ }^{4}$ Faktor abiotik seperti curah hujan, temperatur, dan evaporasi dapat mempengaruhi kegagalan telur, larva, dan pupa nyamuk menjadi imago. Perubahan iklim menyebabkan perubahan curah hujan, suhu, kelembaban, dan arah udara, sehingga berpengaruh terhadap ekosistem daratan dan lautan serta berpengaruh terhadap kesehatan. $^{5}$

Curah hujan mempunyai pengaruh langsung terhadap keberadaan tempat perindukan nyamuk Aedes aegypti. Populasi Aedes aegypti tergantung dari tempat perindukan nyamuk. Curah hujan ( $\mathrm{mm})$ merupakan ketinggian air hujan yang jatuh pada tempat yang datar dengan asumsi tidak menguap, tidak meresap dan tidak mengalir. Curah hujan yang tinggi dan berlangsung dalam waktu yang lama dapat menyebabkan banjir sehingga dapat menghilangkan tempat perindukan nyamuk Aedes yang biasanya hidup di air bersih. Akibatnya jumlah perindukan nyamuk akan berkurang. Namun jika curah hujan kecil dan dalam waktu yang lama akan menambah tempat perindukan nyamuk dan meningkatkan populasi nyamuk. ${ }^{6}$

Kota Bandar Lampung berada di wilayah tropis memiliki curah hujan tahunan yang tinggi, semakin tinggi di daerah pegunungan. Penelitian mengenai hubungan curah hujan dengan kasus demam berdarah dengue di Kota Bandar Lampung telah dilakukan sebelumnya pada periode tahun 20062008 dengan hasil curah hujan yang rendah atau tinggi ternyata tidak selalu diikuti oleh rendah tingginya kasus DBD. Perubahan pola iklim selama sepuluh tahun terakhir yang salah satunya dapat disebabkan olah pemanasan global memiliki pengaruh yang penting terhadap hubungan kedua variabel tersebut . Dinas Kesehatan Kota Bandar Lampung menyatakan bahwa kasus penyakit yang diakibatkan akibat gigitan nyamuk atau DBD sepanjang tahun 2018 sebanyak 914 kasus. Oleh karena itu peneliti ingin mengetahui keterbaruan data mengenai hubungan antara curah hujan dengan kasus DBD di Kota Bandar Lampung tahun 2016-2018.

\section{METODOLOGI}

Jenis penelitian ini merupakan penelitian analitik dengan uji korelasi. Analisis korelasi adalah metode statistika yang digunakan untuk menentukan suatu besaran yang menyatakan bagaimana kuat hubungan suatu variabel dengan variabel lain dengan tidak mempersoalkan apakah suatu variabel tertentu tergantung kepada variabel lain. ${ }^{7}$ Penelitian ini dilakukan untuk mengetahui hubungan dan tingkat hubungan antara dua variabel tersebut. Penelitian dilaksanakan pada bulan Januari Februari 2020 dengan mengambil data prevalensi DBD di Dinkes Bandar Lampung dan data curah hujan di BMKG Bandar Lampung Provinsi Lampung yang kemudian dilakukan analisis. Populasi pada penelitian ini adalah seluruh data prevalensi DBD dan data curah hujan di wilayah kerja Dinkes Kota Bandar Lampung tahun 2016-2018. Penelitian ini menggunakan teknik total sampling di dalam pengambilan samplenya dimana jumlah sampel sama dengan populasi. Data yang digunakan merupakan data sekunder. Data prevalensi DBD per bulan diukur dengan cara observasi dokumen yaitu pengamatan dan pencatatan secara sistematis di wilayah Dinas 
Kesehatan Kota Bandar Lampung tahun 2016 - 2018. Data curah hujan diperoleh dari pencatatan data bulanan di Provinsi Lampung tahun 2016 - 2018 dari Badan Meteorologi, Klimatologi, dan Geofisika (BMKG) Bandar Lampung Provinsi Lampung. Teknik analisis data pada penelitian kuantitatif ini menggunakan uji univariat dan uji bivariat. Sebelum melakukan uji bivariate, peneliti melakukan pengujian normalitas data. Peneliti menggunakan metode analitik. Hal ini dikarenakan metode analitik dengan uji Kolmogorov-Smirnov atau Shapiro-Wilk akan lebih sensitif bila dibandingkan dengan perhitungan koefisien varians. ${ }^{8}$ Penelitian ini memiliki data yang berjumlah dibawah 50 sehingga menggunakan uji normalitas SaphiroWilk. Hasil dari uji normalitas menunjukan bahwa data pada variable kasus DBD tidak terdistribusi secara normal, sehingga uji bivariate yang digunakan adalah uji Spearman.

\section{HASIL DAN PEMBAHASAN}

Kasus demam berdarah dengue di kota Bandar Lampung masih terbilang tinggi. 13 Kecamatan yang ada di kota Bandar Lampung semuanya merupakan daerah endemis DBD dan dari 98 kelurahan yang ada 81 kelurahan merupakan daerah endemis DBD. ${ }^{9}$ Jumlah kasus demam berdarah dengue di kota Bandar Lampung tahun 2016-2018 dapat dilihat pada Gambar 1.

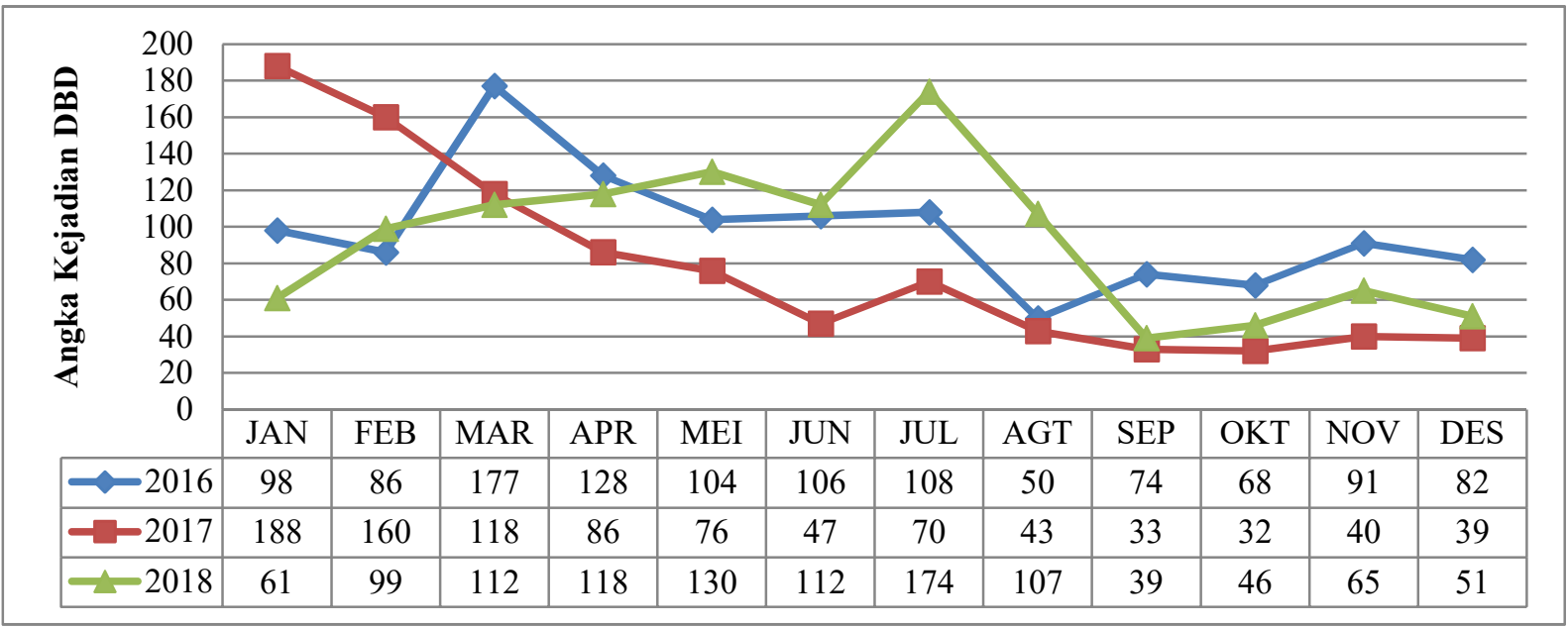

Gambar 1. Jumlah Kasus Demam Berdarah Dengue di Kota Bandar Lampung Tahun 2016-2018

Gambar 1 menunjukan bahwa kasus demam berdarah dengue mengalami jumlah yang berbeda beda pada setiap bulannya. Kasus tertinggi pada tahun 2016 terjadi pada bulan Maret yaitu sebanyak 177 kasus dan kasus terendah terjadi pada bulan Agustus sebanyak 50 kasus. Pada tahun 2017, kasus tertinggi terjadi pada bulan Januari yaitu sebanyak 188 kasus dan kasus terendah terjadi pada bulan Oktober sebanyak 32 kasus. Pada tahun 2018 kasus tertinggi terjadi pada bulan Juli sebanyak 174 kasus dan kasus terendah terjadi pada bulan September sebanyak 39 kasus. Kenaikan kasus demam berdarah dengue terjadi pada tiap awal tahun yaitu mulai bulan Januari sampai Juli pada pertengahan tahun dan kemudian mengalami penurunan. Hal tersebut kurang sesuai dengan penelitian sebelumnya yang dilakukan di Semarang, di mana peningkatan kejadian demam berdarah dengue terjadi pada bulan Oktober sampai Maret pada tahun 2006-2011 sedangkan penurunan terjaid pada bulan April sampai September pada tahun 2006-2011. ${ }^{3}$ Faktor lain yang menyebabkan hal tersebut terjadi kemungkinan disebabkan oleh perubahan iklim (global warming) yang terus terjadi hingga saat ini.

Distribusi frekuensi kasus demam berdarah dengue di kota Bandar Lampung tahun 2016-2018 dapat dilihat pada Tabel 1. 
Tabel 1. Distribusi Kasus Demam Berdarah Dengue di Kota Bandar Lampung 2016-2018

\begin{tabular}{cccc}
\hline Tahun & $\begin{array}{c}\text { Jumlah Kasus } \\
\text { DBD }\end{array}$ & Mean \pm SD & $\begin{array}{c}\text { Median (Min- } \\
\text { Max) }\end{array}$ \\
\hline 2016 & 1172 & $97,67 \pm 32,43$ & $94,50(50-177)$ \\
\hline 2017 & 932 & $77,67 \pm 52,09$ & $58,50(32-188)$ \\
\hline 2018 & 1114 & $92,83 \pm 40,68$ & $103,00(39-174)$ \\
\hline
\end{tabular}

Angka rata-rata kasus demam berdarah paling rendah selama periode 2016-2018 terjadi pada tahun 2017 sebesar 77,67 kasus atau 78 kasus. Sedangkan angka tertinggi terjadi pada tahun 2016 sebesar 97,67 atau sekitar 98 kasus. Hal tersebut memberikan gambaran bahwa terjadi perbedaan angka kejadian yang cukup tinggi diantara kedua tahun tersebut.

Gambaran curah hujan di kota Bandar Lampung tahun 2016-2018 dapat dilihat pada Gambar 2. Curah hujan tertinggi pada tahun 2016 terjadi pada bulan April yaitu sebesar 284,9 mm, kemudian mengalami penurunan hingga mencapai curah hujan terendah sebesar 57,6 mm pada bulan Juli. Pada tahun 2017 curah hujan lebih rendah dibanding tahun 2016 dengan curah hujan tertinggi pada bulan Februari sebesar $247,1 \mathrm{~mm}$ dan curah hujan terendah sebesar $33,3 \mathrm{~mm}$ yang terdapat pada bulan Oktober. Curah hujan pada tahun 2018 mengalami peningkatan dibanding tahun 2017 dengan curah hujan tertinggi sebesar 265,3 mm pada bulan Maret dan penurunan curah hujan terendah terjadi pada bulan Oktober yaitu 52,9 $\mathrm{mm}$.

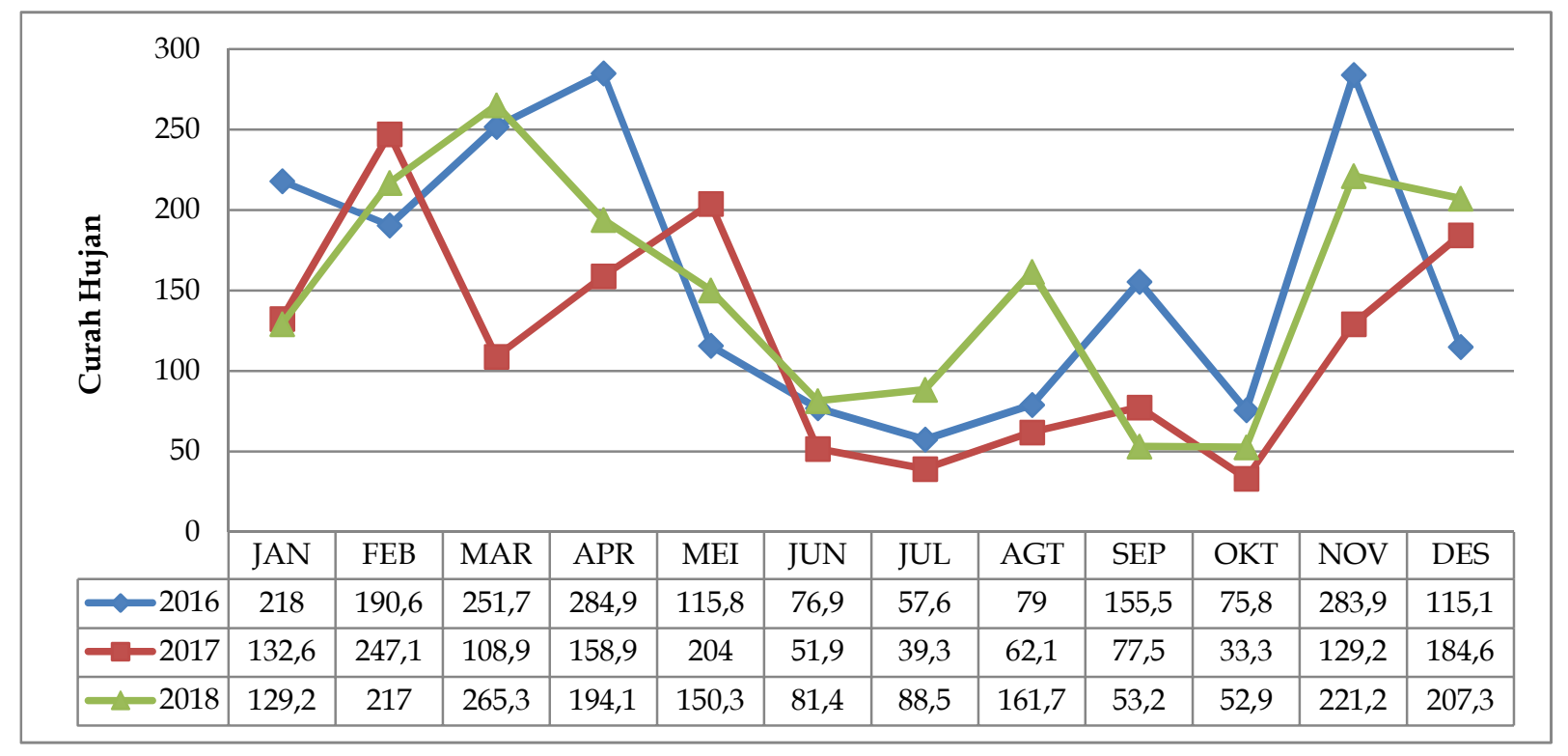

Gambar 2. Kadar Curah Hujan di Kota Bandar Lampung Tahun 2016- 2018

Distribusi frekuensi kadar curah hujan di kota Bandar Lampung tahun 2016-2018 dapat dilihat pada Tabel 2. Hasil analisis data curah hujan di kota Bandar Lampung selama tahun 2016 didapatkan jumlah total curah hujan sebesar 1904,80 mm selama satu tahun dengan rata-rata curah hujan adalah $158,73 \mathrm{~mm}$ per tahun. Tahun 2017 curah hujan yang turun di kota Bandar Lampung relative lebih kecil dengan jumlah total dalam setahun mencapai
$1429,40 \mathrm{~mm}$ dengan rata-rata curah hujan mencapai 119,12 mm per bulannya. Peningkatan terjadi pada tahun 2018 dengan jumlah curah hujan per tahunnya mencapai $1822,10 \mathrm{~mm}$ dengan curah hujan rata-rata $151,84 \mathrm{~mm}$ per bulannya.

Hal tersebut terjadi kemungkinan disebabkan oleh perubahan iklim (global warming) yang terus terjadi hingga saat ini. Hal tersebut sesuai dengan pernyataan Febrianti 
(2018) yang menyatakan bahwa pemanasan global yang akan memicu perubahan iklim berdampak kepada naiknya permukaan air laut, meningkatnya intensitas fenomena cuaca yang ekstrim, serta perubahan jumlah dan pola curah hujan. ${ }^{10}$

Tabel 2. Distribusi Curah Hujan di Kota Bandar Lampung 2016-2018

\begin{tabular}{cccc}
\hline Tahun & $\begin{array}{c}\text { Jumlah Curah } \\
\text { Hujan } \\
(\mathrm{mm})\end{array}$ & Mean \pm SD & Median (Min-Max) \\
\hline 2016 & 1904,80 & $158,73 \pm 84,57$ & $135,65(57,60-284,90)$ \\
\hline 2017 & 1429,40 & $119,12 \pm 69,46$ & $119,05(33,30-247,10)$ \\
\hline 2018 & 1822,10 & $151,84 \pm 71,28$ & $156,00(52,90-265,30)$ \\
\hline
\end{tabular}

Gambaran grafis kasus demam berdarah dengue dan curah hujan di kota Bandar Lampung tahun 2016-2018 dapat dilihat pada Gambar 3. Pola hubungan yang fluktuatif diantara kedua variabel dapat dilihat pada gambar tersebut. Terlihat pola yang berlawanan yang terjadi pada bulan juli dimana kasus DBD meningkat sedangkan jumlah hujan yang rendah.
Sementara pola hubungan fluktuatif antara kedua variabel memberikan gambaran hubungan yang tidak dapat diprediksikan. Hubungan antara kedua variabel dihitung berdasarkan hasil uji Spearman.Hasil uji kekuatan hubungan antara curah hujan dengan kasus demam berdarah dengue pada tahun 2016-2018 ditunjukkan pada Tabel 3 sebagai berikut

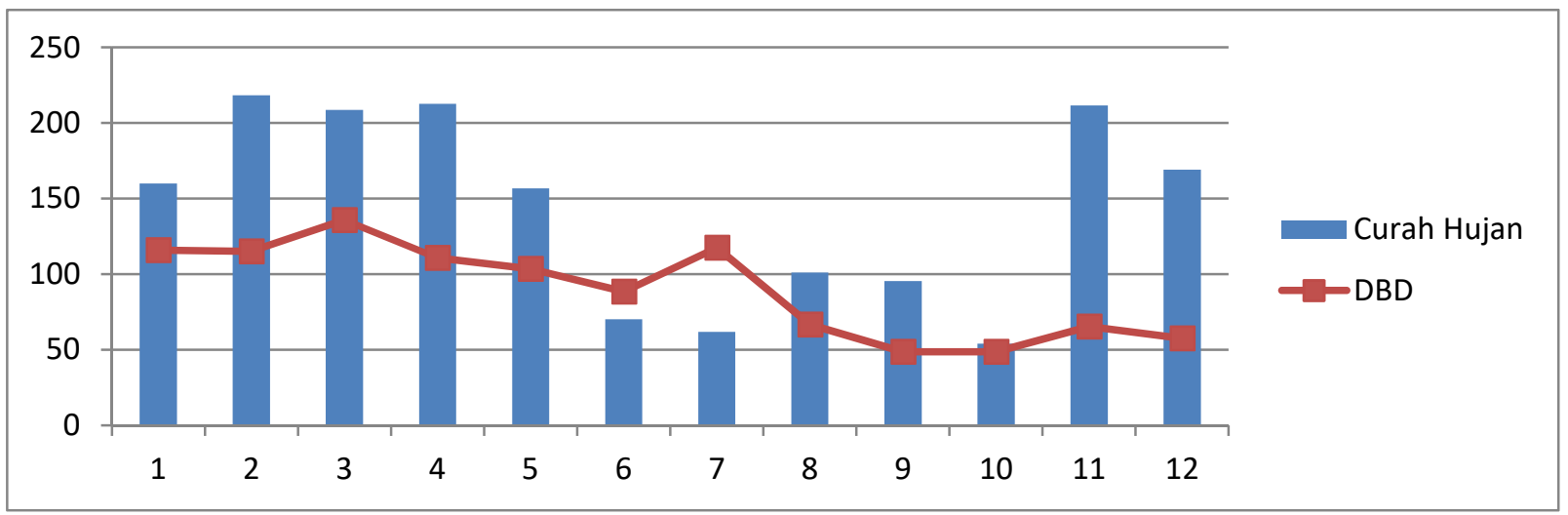

Gambar 3. Kasus Demam Berdarah Dengue dan Curah Hujan di Kota Bandar Lampung Tahun 2016-2018

Tabel 3. Hasil Uji Korelasi Hubungan Kasus DBD dengan Curah Hujan di Kota Bandar Lampung Tahun 2016-2018

\begin{tabular}{cccccc}
\hline Variabel & $\begin{array}{c}\text { Jumlah } \\
(\mathrm{n})\end{array}$ & Mean \pm SD & $\begin{array}{c}\text { Correlation } \\
\text { Coefficient }(\mathrm{r})\end{array}$ & Sig $(\mathrm{p})$ & Keterangan \\
\hline $\begin{array}{c}\text { Curah } \\
\text { Hujan }\end{array}$ & 36 & $143,23 \pm 75,29$ & 0,451 & 0,006 & $\begin{array}{c}\text { Korelasi } \\
\text { sedang, arah } \\
\text { positif, } \\
\text { hubungan } \\
\text { bermakna }\end{array}$ \\
\hline $\begin{array}{c}\text { Kasus } \\
\text { DBD }\end{array}$ & 36 & $89,39 \pm 42,16$ & 0,451 & 0,006 & \\
\hline
\end{tabular}

Hasil pengujian pada variabel curah hujan dan kasus DBD menunjukkan nilai $r$ hitung sebesar 0,451 , nilai $\mathrm{N}$ sebesar 36 sampel dan signifikasi 0,006 . Nilai $r$ hitung menunjukan bahwa variable mempunyai kekuatan hubungan sedang dan berpola positif yang artinya jumlah kasus demam berdarah dengue akan meningkat bila curah hujan meningkat. Nilai signifikan atau $\mathrm{p}=0,006$, sehingga dapat disimpulkan bahwa ada hubungan bermakna antara curah hujan selama tahun tahun 2016 - 2018 dengan kasus demam berdarah dengue karena nilai $\mathrm{p}$ lebih kecil dari $\alpha(0,05)$. Hasil penelitian ini sejalan dengan penelitian Nuryati (2012) yang menyatakan di dalam jurnalnya yang berjudul Analisis Spasial Kasus Demam Berdarah 
Dengue di Kota Bandar Lampung Tahun 20062008 bahwa terdapat hubungan yang signifikan antara curah hujan dengan kasus demam berdarah dengue di kota Bandar Lampung tahun 2006-2008. ${ }^{8}$

\section{KESIMPULAN DAN SARAN}

Berdasarkan hasil penelitian dan pembahasan tentang Hubungan Curah Hujan Dengan Kasus Demam Berdarah Dengue (DBD) Di Kota Bandar Lampung Tahun 2016-2018, maka diketahui terdapat hubungan curah hujan dengan kasus DBD di kota Bandar Lampung Tahun 2016-2018 dengan kekuatan korelasi yang sedang dimana curah hujan memberikan peran terhadap timbulnya kasus DBD tetapi tidak bersifat mutlak karena masih dapat dipengaruhi oleh faktor lainnya seperti faktor temperatur, kelembaban dan suhu udara serta arah positif yang memiliki arti peningkatan angka kasus DBD berjalan lurus dengan peningkatan curah hujan.

Peneliti menyarankan kepada masyarakat untuk tetap waspada akan penyakit demam berdarah dengue terutama ketika curah hujan meningkat. Selalu membersihkan daerah yang menggenang dan menjaga imunitas tubuh. Bagi Puskesmas peneliti berharap agar pihak puskesmas dapat memberikan penyuluhan mendalam terhadap masyarakat untuk waspada terhadap DBD dengan mengajarkan prevensi terhadap penyakit DBD serta mengajarkan pola hidup bersih dan sehat. Bagi penelitian selanjutnya peneliti menyarankan untuk penelitian selanjutnya agar menggunakan variabel yang lain sehingga dapat ditemukan hubungan korelasi yang kuat antara DBD dengan faktor faktor pencetus nya.

\section{UCAPAN TERIMA KASIH}

Peneliti mengucapkan terima kasih kepada kepada Kesbangpol yang telah membantu dalam kelancaran penelitian ini. Peneliti juga megucapkan terima kasih kepada Dinas Kesehatan Kota Bandar Lampung dan Badan Meteorologi, Klimatologi, dan Geofisika (BMKG) Bandar Lampung Provinsi Lampung. yang telah memberikan informasi yang sangat membantu didalam penyusunan penelitian ini. Terima kasih juga kepada semua pihak yang berperan dalam pelaksanaan penelitian ini .

\section{REFERENSI}

1. Widoyono. Penyakit Tropis, Epidemiologi, Penularan, Pencegahan dan Pemberantasannya. Jakarta: Erlangga ; 2015.

2. Kemenkes RI. Profil Kesehatan Indonesia Tahun 2015. Jakarta: Kemenkes RI; 2015.

3. Wirayoga. Hubungan Kejadian Demam Berdarah Dengue Dengan Iklim Di Kota Semarang tahun 2006 -2011. [Skripsi]. Fakultas Ilmu Keolahragaan. Universitas Negeri Semarang. Semarang; 2013.

4. Raksanagara SA. Dampak Perubahan Iklim Terhadap Kejadian Demam Berdarah di Jawa Barat. Jurnal Kesehatan Masyarakat Universitas Padjajaran. 2015; Vol I (1).

5. Iriani. Hubungan antara Curah Hujan dan Peningkatan Kasus Demam Berdarah Dengue Anak di Kota Palembang. Jurnal Sari Pediatri. 2012; Vol. 3(6).

6. Majidah A. Faktor Iklim dan Angka Insiden Demam Berdarah Dengue di Kabupaten Serang.http://journal.ui.ac.id/index.php/health/art icle/viewFile/644, 2010.

7. Sekaran, Uma, Bougie, R., 2010, Research Methods for Business: A SkillBuilding Approach. London: John Wiley and sons, inc. ;2010.

8. Nuryati E. Thamrin. Analisis Spasial Kejadian Demam Berdarah Dengue Di Kota Bandar Lampung Tahun 2006-2008. Jurnal Ilmiah Kesehatan. 2012; Vol 1 (2).

9. Dahlan S. Statistik untuk Kedokteran dan Kesehatan. Jakarta: Salemba Merdeka; 2009.

10. Febrianti, N. Hubungan Pemansan Global dengan Kondisi Suhu Udara dan Curah Hujan di Indonesia. Jurnal LAPAN;2009. 